Sciscitatio, Januari 2020

Vol. 1, No. 1: 14-22

\title{
Uji Antifungi Susu Fermentasi Komersial pada Candida non-albicans
}

\section{Antifungal Activity of Commercial Fermented Milk against Candida non-albicans}

\author{
Nur Khikmah ${ }^{1 *}$ dan Nunung Sulistyani ${ }^{1}$ \\ ${ }^{1}$ Akademi Analis Kesehatan Manggala, Yogyakarta, Indonesia
}

\begin{abstract}
Abstrak
Bakteri Asam Laktat (BAL) yang terkandung dalam susu fermentasi akan menghasilkan asam-asam organik, hidrogen peroksida, diasetil, asetaldehid, asetoin, reutinin, reuterisiklin dan bakteriosin, dapat sebagai anti-Candida. Spesies Candida non-albicans seperti C. tropicalis dan C. glabrata sebagai penyebab kandidiasis oral cenderung meningkat. Tujuan penelitian ini mengetahui aktivitas antifungi susu fermentasi komersial pada Candida non-albicans dan viabilitas bakteri asam laktat di dalam susu fermentasi komersial. Aktivitas antifungi pada Candida non-albicans dilakukan dengan metode difusi sumuran. Viabilitas bakteri asam laktat dihitung berdasarkan jumlah bakteri asam laktat sebagai jumlah bakteri total (Total Plate Count). Hasil penelitian menunjukkan bahwa susu fermentasi komersial lebih mampu menghambat $C$. tropicalis dibandingkan $C$. glabrata. Viabilitas bakteri asam laktat dalam susu fermentasi komersial $10^{7}-10^{10} \mathrm{CFU} / \mathrm{mL}$.
\end{abstract}

Kata kunci: susu fermentasi, Candida non-albicans, bakteri asam laktat

\begin{abstract}
Lactic Acid Bacteria (LAB) contained in fermented milk will produce organic acids, hydrogen peroxide, diacetyl, acetaldehyde, acetoin, reutinin, reuterycline and bacteriocin, as anti-Candida. Candida non-albicans species such as $C$. tropicalis and C. glabrata as causes of oral candidiasis tend to increase. The aim of this research was to determine the antifungal activity of commercial fermented milk against Candida non-albicans and viability of lactic acid bacteria in commercial ermented milk. The antifungal activity was determined using well diffusion method. Viability of lactic acid bacteria is calculated as Total Plate Count. The results showed that commercial fermented milk was more able to inhibit C. tropicalis compared C. glabrata. Viability of lactic acid bacteria $10^{7}-10^{10} \mathrm{CFU} / \mathrm{mL}$.
\end{abstract}

Keywords: fermented milk, Candida non-albicans, lactic acid bacteria

\footnotetext{
* Corresponding Author:

Nur Khikmah

Akademi Analis Kesehatan Manggala Yogyakarta

Jl. Bratajaya No. 25, Sokowaten, Banguntapan, Bantul, Indonesia

E-mail : khikmahnr@gmail.com
} 


\section{Pendahuluan}

Susu fermentasi didefinisikan sebagai produk susu yang melibatkan mikroba untuk menghasilkan rasa, warna, tekstur dan konsistensi yang diinginkan dan mampu mencegah lactose intolerance. Produk susu fermentasi yang umum dikonsumsi adalah yakult, yoghurt, dan kefir. Produk tersebut dibedakan berdasarkan adalah jenis mikroba yang memfermentasi. Mikroba yang berperan penting dalam fermentasi susu adalah kelompok Bakteri Asam Laktat (BAL) (Wibowo, 2002). Selama proses fermentasi, BAL akan menghasilkan asamasam organik (asam laktat, asam asetat dan asam format), hidrogen peroksida, diasetil, asetaldehid, asetoin, reutinin, reuterisiklin dan bakteriosin. Senyawa yang dihasilkan tersebut dapat bersifat anti-Candida (Suskovic et al., 2010).

Pada produk susu fermentasi dapat ditambahkan bakteri probiotik. Probiotik sebagian besar adalah BAL golongan Lactobacillus dan Bifidobacterium (Adriani, 2010). Penambahan bakteri probiotik ditujukan agar mempunyai efek fungsional bagi kesehatan (Irianto, 2013). Penelitian yang dilakukan oleh Khikmah dan Sulistyani (2017), mendapatkan susu fermentasi komersial dengan kandungan Lactobacilus acidophilus, Bifidobacterium, S. thermophilus, dan Lactobacilus burgaricus mampu menghambat Candida albicans dengan diameter zona hambat tertinggi.

Candida merupakan genus penyebab kandidiasis oral, yaitu kelainan pada mukosa rongga mulut. Kandidiasis tersebut dapat terjadi karena pengobatan antibiotik dalam jangka waktu lama dan pada kondisi imunosuspression (pasien kanker, diabetes, Acquired Immunodeficiency Syndrome/AIDS) (Hakim \& Ramadhian, 2015). Sebagian besar kandidiasis oral disebabkan oleh Candida albicans (CA), dapat juga disebabkan oleh non-Candida albicans Candida (NCAC), yaitu C. tropicalis, C. krusei, C. parapsilosis, dan C. guilliermondi (Gravina et al., 2007).
Lukisari et al. (2010), melaporkan bahwa C. tropicalis dapat diisolasi pada kandidiasis oral dari pasien anak dengan gangguan sistemik. Walangare et al. (2014), juga berhasil mengidentifikasi Candida non-albicans sebagai penyebab Kandidiasis Oral pada pasien HIV \& AIDS di RSUD Dr. Saiful Anwar Malang. Ditemukan spesies C. albicans $(88,8 \%)$, C. glabrata $(7,4 \%)$, dan C. tropicalis $(3,8 \%)$.

Penelitian Pfaller et al. (2007), menyebutkan secara epidemiologi dari tahun 1999-2003 spesies C. albicans tetap spesies terbanyak yang menyebabkan infeksi di Amerika Serikat, meskipun kecenderungan terus menurun dari tahun 1992 sebesar $52 \%$ menjadi $45 \%$ pada tahun 2000 . Spesies Candida non-albicans seperti C. glabrata, C. parapsilosis, C. krusei, dan C. tropicalis cenderung meningkat. Pada tahun 19922000 terjadi peningkatan insiden infeksi oleh C. glabrata dari $12 \%$ menjadi $24 \%$ sehingga spesies ini dikatakan sebagai spesies opurtunistik yang paling berkembang di Amerika Serikat. Penelitian Hasrulliana et al. (2010), menyebutkan dominasi spesies Candida non-albicans $(65,62 \%)$ yang terdiri dari C. tropicalis $(29,41 \%)$, C. dubliniensis $(14,71 \%)$, C. glabrata $(14,71 \%)$, dan C. guillermondii $(5,88 \%)$ dibandingkan spesies C.albicans $(34,38 \%)$ pada kandidiasis oral penderita HIV/ AIDS RSUD Dr. Soetomo.

Produk minuman susu fermentasi komersial telah banyak beredar di pasaran dengan berbagai macam merk. Informasi tentang manfaat susu fermentasi masih terbatas pada kemampuan dalam mencegah dan mengobati infeksi bakteri pada saluran pencernaan. Berdasarkan hal tersebut penelitian tentang aktivitas antifungi susu fermentasi komersial pada Candida, khususnya Candida non-albicans penyebab kandidiasis oral dan viabilitas bakteri di dalam susu fermentasi perlu dilakukan. Penelitian ini dilakukan untuk mengetahui aktivitas antifungi susu fermentasi komersial pada Candida non-albicans dan viabilitas 
bakteri di dalam susu fermentasi. Penelitian ini diharapkan menjadi rujukan dalam menjadikan susu fermentasi sebagai salah satu alternatif dalam pencegahan infeksi oleh Candida non-albicans pada kandidiasis oral.

\section{Materi dan Metode Persiapan sampel}

Sampel susu fermentasi diperoleh dengan cara membeli produk susu fermentasi di toko swalayan yang ada di Yogyakarta. Sampel terdiri dari berbagai jenis dan merk susu fermentasi, dipilih yang belum melampaui batas kadaluwarsa. Jumlah susu fermentasi adalah 12 sampel, disimpan di almari pendingin sampai akan digunakan.

\section{Pembuatan Suspensi Candida non-albicans}

Kultur Candida non-albicans yang digunakan adalah C. tropicalis FNCC 3023 (koleksi PAU Pangan dan Gizi UGM) dan C. glabrata InaCC Y 68 (koleksi LIPI Cibinong). Kultur uji diinokulasikan pada medium Saboraud Dextrose Agar (SDA) miring, diinkubasi pada suhu kamar selama 24 jam. Suspensi Candida uji dibuat dengan cara mengambil 1 ose dari kultur stock Candida pada medium SDA miring, dibuat suspensi menggunakan larutan $\mathrm{NaCl}$ 0,85\% steril. Suspensi distandarkan kekeruhannya sampai $10^{8} \mathrm{CFU} / \mathrm{mL}$ menggunakan standart Mc Farland I sebagai pembanding kekeruhan (NCCLS, 2002).

\section{Uji Antifungi Susu Fermentasi Komersial pada Candida non-albicans}

Uji antifungi susu fermentasi komersial pada Candida non-albicans dilakukan dengan metode difusi sumuran (well diffusion methods) (Purwijantiningsih, 2011). Suspensi C. nonalbicans uji sebanyak 0,1\% diinokulasikan pada cawan petri yang berisi $30 \mathrm{~mL}$ media SDA secara pour plate. Media ditunggu sampai membeku, selanjutnya dibuat 6 sumuran dengan diameter $5 \mathrm{~mm}$. Pada 5 sumuran dimasukan $60 \mu \mathrm{L}$ susu fermentasi dengan merk yang berbeda. Kontrol negatif digunakan Dimethyl sulfoxide (DMSO) dan kontrol positif adalah nistatin dalam bentuk disc antifungi (100 units). Selanjutnya diinkubasi pada suhu kamar selama 72 jam. Kemampuan antifungi susu fermentasi pada Candida non-albicans ditunjukan adanya zona jernih di sekitar sumuran, diukur sebagai mm diameter zona jernih dikurangi diameter sumuran.

\section{Viabilitas Bakteri}

Viabilitas bakteri dihitung berdasarkan jumlah bakteri asam laktat yang ada di dalam susu fermentasi, dihitung dengan metode hitungan cawan (plate count) (Akalin et al., 2004). Setiap susu fermentasi dibuat seri pengenceran sampai $10^{-6}$. Pada pengenceran $10^{-5}$ dan $10^{-6}$ dilakukan pour plating pada medium De Man Rogosa Sharpe Agar (MRSA), kemudian diinkubasi pada suhu kamar

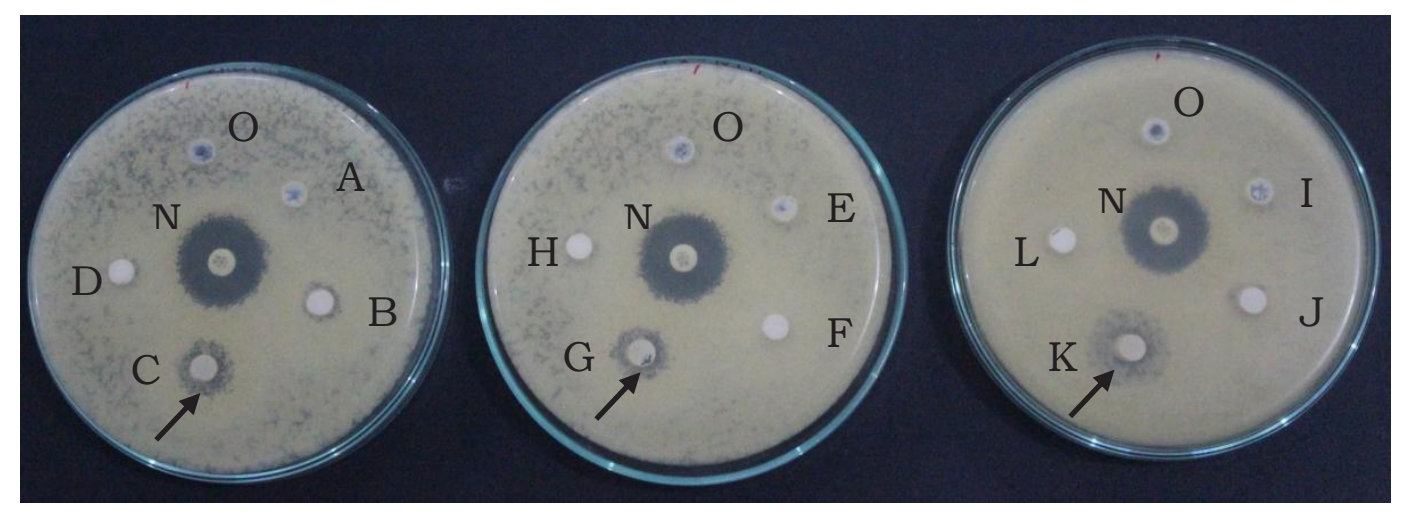

Gambar 1. Uji antifungi susu fermentasi komersial pada C. tropicalis dengan waktu inkubasi $3 \times 24$ jam. Keterangan : $\mathrm{N}=$ nistatin, $\mathrm{O}=\mathrm{DMSO}$ dan $\mathrm{A}-\mathrm{L}=$ susu fermentasi komersial. Tanda panah $(\boldsymbol{\lambda})$ menunjukkan zona irradikal. 


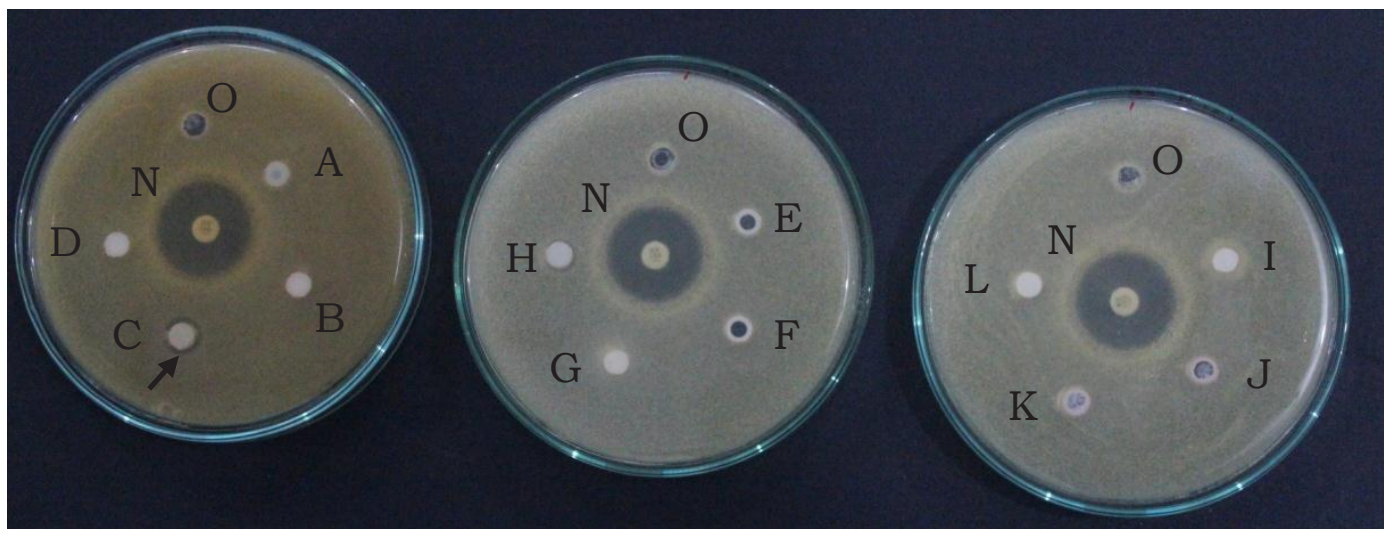

Gambar 2. Uji antifungi susu fermentasi komersial pada C. glabrata dengan waktu inkubasi $3 \times 24$ jam. Keterangan : $\mathrm{N}=$ nistatin, $\mathrm{O}=\mathrm{DMSO}$ dan $\mathrm{A}-\mathrm{L}=$ susu fermentasi komersial. Tanda panah $(\boldsymbol{\lambda})$ menunjukkan zona irradikal.

selama 72 jam. Diamati koloni Bakteri Asam Laktat (BAL) yang tumbuh dan dilakukan perhitungan jumlah koloni sebagai Total Plate Count (TPC).

\section{Pengukuran $\mathrm{pH}$}

Pengukuran $\mathrm{pH}$ dilakukan dengan mencelupkan $\mathrm{pH}$ meter ke dalam susu fermentasi, ditunggu sampai angka pada layar pH meter konstan (Akalin et al., 2004).

\section{Hasil}

Uji antifungi susu fermentasi komersial menunjukkan bahwa susu fermentasi ada yang mempunyai aktivitas antifungi dan ada yang tidak mempunyai aktivitas antifungi pada C. tropicalis (Gambar 1) dan pada C. glabrata (Gambar 2). Adanya aktivitas antifungi tersebut ditunjukkan dengan terbentuknya zona hambat di sekitar sumuran. Zona hambat tersebut termasuk dalam kategori zona irradikal.

Diameter zona irradikal yang dihasilkan oleh susu fermentasi komersial disajikan pada Tabel 1.

Susu fermentasi komersial mengandung bakteri asam laktat yang berbeda. Bakteri asam laktat yang terdapat dalam susu fermentasi disajikan pada Tabel 2.

Koloni BAL yang tumbuh pada medium MRSA disajikan pada Gambar 3. BAL tumbuh membentuk zona jernih.
Viabilitas BAL ditentukan dengan menghitung bakteri hidup yang terdapat dalam susu fermentasi. Jumlah BAL total yang terkandung pada 12 susu fermentasi komersial dan $\mathrm{pH}$ disajikan pada Tabel 3.

\section{Pembahasan}

Adanya aktivitas antifungi susu fermentasi komersial pada $C$. tropicalis dan C. glabrata ditunjukkan dengan terbentuknya zona irradikal di sekitar sumuran (Gambar 1 dan 2). Zona irradikal menunjukkan bahwa

Tabel 1. Rata-rata diameter zona irradikal susu fermentasi komersial pada C. tropicalis dan C. glabrata

\begin{tabular}{ccc}
\hline \multirow{2}{*}{ Susu Fermentasi } & \multicolumn{2}{c}{ Diameter Zona Irradikal $(\mathrm{mm})$} \\
\cline { 2 - 3 } & C. tropicalis & C. glabrata \\
\hline A & 0 & 0 \\
B & 6 & 3 \\
C & 9 & 0 \\
D & 0 & 0 \\
E & 0 & 0 \\
F & 0 & 0 \\
G & 8 & 0 \\
H & 0 & 0 \\
I & 0 & 0 \\
J & 15 & 0 \\
K & 5 & 0 \\
L & 0 & 0 \\
DMSO & 0 & 0 \\
Nistatin & 17 & 15 \\
\hline
\end{tabular}


Khikmah et al.

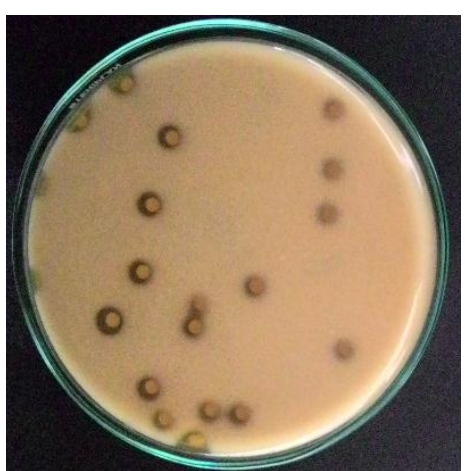

Gambar 3. Koloni BAL tumbuh pada medium MRSA membentuk zona jernih

Tabel 2. Bakteri Asam Laktat (BAL) yang terkandung dalam susu fermentasi komersial

\begin{tabular}{|c|c|}
\hline $\begin{array}{c}\text { Susu } \\
\text { Fermentasi }\end{array}$ & Bakteri Asam Laktat \\
\hline $\mathrm{A}$ & Lactobacillus casei strain Shirota \\
\hline B & $\begin{array}{l}\text { L. acidophilus, Bifidobacterium, } \\
\text { Streptococcus thermophilus }\end{array}$ \\
\hline C & $\begin{array}{l}\text { Bifidobacterium BB-12, L. acidophilus } \\
\text { LA-5 }\end{array}$ \\
\hline $\mathrm{D}$ & L. bulgaricus \\
\hline $\mathrm{E}$ & Kultur BAL \\
\hline $\mathrm{F}$ & $\begin{array}{l}\text { S. thermophilus, L. delbrueckii Sub sp } \\
\text { bulgaricus }\end{array}$ \\
\hline G & $\begin{array}{l}\text { L. thermophilus, L. bulgaricus, } \\
\text { L. acidophilus, Bifidobacterium }\end{array}$ \\
\hline $\mathrm{H}$ & $\begin{array}{l}\text { L. thermophilus, L. bulgaricus, L. } \\
\text { acidophilus, Bifidobacterium }\end{array}$ \\
\hline I & $B A L+$ Khamir \\
\hline $\mathrm{J}$ & $\begin{array}{l}\text { L. acidophilus, Bifidobacterium, S. } \\
\text { thermophilus, L. bulgaricus }\end{array}$ \\
\hline K & Yoghurt Skim \\
\hline $\mathrm{L}$ & L. bulgaricus, L. acidophilus \\
\hline
\end{tabular}

Tabel 3. Jumlah BAL dan $\mathrm{pH}$ susu fermentasi komersial

\begin{tabular}{ccc}
\hline Susu Fermentasi & Jumlah BAL $(\mathrm{CFU} / \mathrm{mL})$ & $\mathrm{pH}$ \\
\hline A & $9,9 \times 10^{7}$ & 3,4 \\
B & $8,4 \times 10^{10}$ & 3,9 \\
C & $3,8 \times 10^{7}$ & 3,5 \\
D & $2,5 \times 10^{7}$ & 3,3 \\
E & $4,1 \times 10^{7}$ & 3,9 \\
F & $1,1 \times 10^{7}$ & 3,8 \\
G & $2,3 \times 10^{7}$ & 4,2 \\
H & $3,1 \times 10^{7}$ & 3,7 \\
I & $1,0 \times 10^{7}$ & 3,01 \\
J & $1,9 \times 10^{8}$ & 4,1 \\
K & $9,5 \times 10^{9}$ & 4,3 \\
L & $1,9 \times 10^{7}$ & 4,1 \\
\hline
\end{tabular}

Sciscitatio, Vol. 1, No. 1, Januari 2020

susu fermentasi komersial mempunyai potensi menghambat $C$. tropicalis dan C. glabrata tetapi belum mempunyai kemampuan mematikan.

Kemampuan antifungi susu fermentasi pada C. tropicalis dan C. glabrata dikarenakan selama fermentasi bakteri asam laktat yang terkandung dalam susu fermentasi mampu menghasilkan senyawa antifungi, diantaranya asam-asam organik (asam laktat, asam asetat), hidrogen peroksida, diasetil dan bakteriosin. Dalam penelitian ini belum diidentifikasi jenis senyawa antifungi yang dihasilkan. Kemampuan antifungi susu fermentasi pada C. tropicalis dan C. glabrata berbeda-beda (Tabel 1). Perbedaan tersebut dikarenakan adanya perbedaan komposisi dan jumlah BAL dalam susu fermentasi (Tabel 2), sehingga aktivitas senyawa-senyawa antifungi yang dihasilkan juga berbeda. Pada penelitian ini, kemampuan antifungi susu fermentasi kemungkinan disebabkan oleh asam organik. Hal ini ditandai dengan terbentuknya zona irradikal. Menurut Rai et al. (2009), aktivitas antimikroba asam organik dapat dibedakan dengan aktivitas bakteriosin. Bakteriosin akan menghasilkan zona jernih yang jelas, bulat dan luas. Zona jernih tersebut termasuk dalam zona radikal, yang menunjukkan bahwa senyawa antimikroba mampu mematikan mikroba uji.

Efek penghambatan asam organik terutama disebabkan oleh molekul asam yang tidak terdisosiasi, berdifusi melintasi membran sel menuju sitoplasma yang lebih basa. Hal tersebut mengganggu fungsi metabolik yang penting (Suskovic et al., 2010). Diantaranya mengganggu transpor nutrisi ke dalam sel dan menyebabkan metabolit internal keluar dari sel, yang akhirnya akan menyebabkan kerusakan sel (Parada et al., 2007).

Susu fermentasi komersial dalam menghambat $C$. tropicalis dan C. glabrata mempunyai aktivitas yang berbeda-beda. Hal tersebut ditunjukkan oleh perbedaan diameter zona irradikal yang terbentuk 
(Tabel 1). Susu fermentasi (B, C, G, J dan $\mathrm{K})$ mampu menghambat pertumbuhan $C$. tropicalis, dengan aktivitas antifungi tertinggi pada susu fermentasi J. Susu fermentasi yang dapat menghambat pertumbuhan C. glabarta hanya susu fermentasi B. Hasil tersebut menunjukkan bahwa susu fermentasi lebih mampu menghambat C. tropicalis dibandingkan C. glabrata.

Hasil berbeda diperoleh pada penelitian Adeniyi et al. (2011), supernatan yang dihasilkan oleh BAL dari salad sayuran lebih mampu menghambat $C$. glabrata UCH 1208 dibandingkan C. tropicalis UHC 1408. Lactobacillus mesenteroides lebih mampu menghambat C. glabarta UCH 1208 dibandingkan C. tropicalis UHC 1408. L. brevis hanya dapat menghambat $C$. tropicalis. L. delbruesckii, L. plantarum dan Pediococcus spp. hanya mampu menghambat C. glabarta UCH 1208.

Bakteri asam laktat (Lactobacillus plantarum, L. curvatus, Pediococcus acidilactici, dan $P$. pentosaceus) yang diisolasi dari madu alam mampu menghambat semua Candida uji, yaitu C. albicans ATCC 14053, C. glabrata ATCC 2001, C. krusei ATCC 6258, C. parapsilosis ATCC 22019, dan C. tropicalis ATCC 750. Penghambatan tinggi terjadi pada C. glabrata oleh L. curvarus dan P. pentocaeus. Hasil uji supernatan dari keempat BAL juga mampu menghambat semua Candida uji (diameter hambat 10 - $22 \mathrm{~mm}$ ). Supernatan L. curvatus tertinggi dalam menghambat $C$. glabrata (diameter hambat $22 \mathrm{~mm}$ ). Diameter zona hambat supernatan BAL terhadap $C$. glabrata lebih tinggi dibandingkan $C$. tropicalis (Bulgasem et al., 2016).

Hasil penelitian Biyari dan Fozouni (2018), supernatan dari bakteri probiotik Leuconostoc mesenteroides, Lactobacillus plantarum (diisolasi dari yoghurt lokal, yoghurt Poonak, susu domba dan susu sapi) dan Lactobacillus divergence efektif menghambat pertumbuhan Candida spesies yang diisolasi dari mulut dan air liur lansia. Penghambatan Leuconostoc mesenteroides dan
Lactobacillus plantarum pada C. albicans, C. glabarta, C. kefyr dan C. tropicalis lebih efektif dibandingkan Lactobacillus divergence.

Adanya perbedaan hasil penelitian ini dengan penelitian sebelumnya dikarena perbedaan senyawa yang diujikan. Pada penelitian ini senyawa yang diujikan masih tercampur dalam susu fermentasi, sedangkan pada penelitian sebelumnya senyawa dalam bentuk supernatan bebas sel. Senyawa antifungi dalam supernatan lebih murni dibandingkan senyawa yang masih tercampur dalam susu fermentasi, sehingga aktivitas antifungi juga lebih tinggi.

Coman et al. (2014), melakukan uji aktivitas antimikroba bakteri probiotik pada patogen, metode yang digunakan salah satunya modified cross-streak. Hasil menunjukkan Lactobacillus rhamnosus IMC $501{ }^{\circledR}$ mempunyai kemampuan tinggi dalam menghambat C. albicans (ATTC 10261 dan ISS7). Lactobacillus paracasei IMC $502^{\circledR}$ mampu menghambat dengan kategori tinggi pada semua Candida yang diujikan, kecuali $C$. glabarta ISS3 dan C. tropicalis ISS6 tidak mampu dihambat. Kombinasi kedua bakteri probiotik tersebut (1:1) dalam SYNBIO ${ }^{\circledR}$ mempunyai aktivitas fungisida. Kemampuan penghambatan tinggi ditunjukkan pada $C$. albicans ATCC 10261, ISS2, ISS7, ISS1 dan C. krusei ISS4, diikuti pada C. parasilosis ISS5. Pada C. glabrata ISS3 dan C. tropicalis ISS6 tidak terjadi penghambatan. Hasil penelitian juga menunjukkan bahwa Lactobacillus paracasei IMC $502^{\circledR}$ dan $S Y \mathrm{NBIO}^{\circledR}$ mempunyai kemampuan menghambat semua Candida yang diujikan dibandingkan Lactobacillus rhamnosus IMC $501^{\circledR}$.

Koloni BAL yang tumbuh pada medium MRSA (Gambar 3), membentuk zona jernih. Menurut Hartayanie et al. (2015), zona jernih yang terbentuk menunjukan kemampuan BAL menggunakan sumber karbon untuk menghasilkan metabolit sekunder berupa asam. Asam yang dihasilkan mampu mendegradasi $\mathrm{CaCO}_{3}$ pada medium, menghasilkan kalsium laktat $\left(\mathrm{C}_{6} \mathrm{H}_{10} \mathrm{CaO}_{6}\right)$ 
yang larut dalam medium dan terlihat sebagai zona jernih.

Viabilitas bakteri asam laktat dalam susu fermentasi merupakan hal yang penting berkaitan dengan senyawa-senyawa yang dihasilkan yang dapat menghambat pertumbuhan mikroba termasuk Candida. Viabilitas BAL ditentukan dengan menghitung bakteri hidup yang terdapat dalam susu fermentasi (Tabel 3). Dua belas sampel susu fermentasi mengandung jumlah BAL yang telah memenuhi standar yang ditetapkan, yaitu $10^{7}-10^{10} \mathrm{CFU} / \mathrm{mL}$.

Susu fermentasi agar memberikan manfaat kesehatan, maka jumlah bakteri probiotik $10^{6}-10^{8} \mathrm{CFU} / \mathrm{mL}$ produk. Hal ini bertujuan untuk mengimbangi kemungkinan penurunan jumlah bakteri probiotik pada saat berada dalam saluran pencernaan (Shah ,2000). Dosis yang direkomendasikan $10^{7}-10^{10}$ CFU (Colony Forming Unit) setiap serving dan setiap hari dapat mengkonsumsi 1-4 serving (Lee, 2009 dalam Rahayu et al., 2013).

Beberapa penelitian juga memperoleh jumlah bakteri asam laktat sesuai dengan standar yang ditetapkan. Guevarra et al. (2015), melakukan perhitungan jumlah bakteri asam laktat pada yoghurt komersial di Philipina. Jumlah Streptococcus thermophilus dan Lactobacillus bulgaricus dalam 7 (tujuh) yoghurt komersial memenuhi batas minimal $10^{6} \mathrm{CFU} / \mathrm{mL}$ yang direkombinasikan untuk kesehatan dan efek terapi. Pada 4 (empat) yoghurt komersial rata-rata $S$. thermophilus lebih tinggi dari L. bulgaricus. da Silva et al. (2013), jumlah bakteri asam laktat pada yoghurt susu kambing adalah 2,6 x 107-1,8 $x 10^{8} \mathrm{CFU} / \mathrm{mL}$. Yoghurt disimpan selama 29 hari, pada $4^{\circ} \mathrm{C}$. Perhitungan bakteri dilakukan dengan interval waktu 7 (tujuh) hari. Khalil dan Anwar (2016), jumlah bakteri asam laktat (CFU/mL) dari 4 (empat) yoghurt komersial adalah $7,2 \times 10^{6} ; 1,0 \times 10^{6}$; $5,6 \times 10^{7}$; dan $1,5 \times 10^{7}$.

Urbiene dan Leskauskaite (2006), asam laktat merupakan hasil utama fermentasi laktosa dalam susu dan produk susu oleh bakteri. Tergantung dari jenis BAL yang memfermentasi, maka dapat melalui jalur glikolisis menghasilkan asam laktat atau jalur pentosa phosphat menghasilkan asam laktat dan asam asetat. Dihasilkannya asam-asam tersebut menyebabkan penurunan $\mathrm{pH}$ susu fermentasi

Derajat keasaman $(\mathrm{pH})$ mempunyai peran penting dalam aktivitas anti-Candida. Aktivitas akan stabil pada $\mathrm{pH} 3,0-5,0$. Nilai pH melebihi 5,0 menunjukkan efek sinergis antara asam laktat dan senyawa antifungi lainnya (Magnusson \& Schnurer, 2001). Nilai pH yoghurt komersial 3,5-4,3 (Bamise \& Bamise, 2008). Pada penelitian ini susu fermentasi mempunyai $\mathrm{pH}$ 3,5-4,3. Berdasarkan hal tersebut, kemungkinan aktivitas penghambatan $C$. non albicans pada penelitian ini dikarenakan oleh asam organik. Hasil penelitian Bulgasem et al. (2017), supernatan dari L. curvatus dan $P$. pentosaceus dengan $\mathrm{pH} 3$ mempunyai kemampuan antifungi tinggi pada C. glabrata ATCC 2001.

\section{Kesimpulan}

Susu fermentasi komersial lebih mampu menghambat $C$. tropicalis dibandingkan $C$. glabrata. Viabilitas bakteri asam laktat dalam susu fermentasi komersial $10^{7}-10^{10} \mathrm{CFU} / \mathrm{mL}$.

\section{Ucapan Terima Kasih}

Terima kasih disampaikan kepada Direktorat Riset dan Pengabdian Kepada Masyarakat Kemristekdikti melalui Hibah Penelitian Dosen Pemula dengan Nomor Kontrak: 044/HB-LIT/III/ 2016 tanggal 15 Maret 2016 dan Akademi Analis Kesehatan Manggala Yogyakarta melalui anggaran rutin Unit Penelitian dan Pengabdian Masyarakat (UPPM) 2015/2016.

\section{Daftar Pustaka}

Adriani, L. (2010). YoghurtSebagai Probiotik. Dalam: Soeharsono (eds), Probiotik. Widya Padjadjaran, Bandung, hlm 117-130. 
Adeniyi, B \& Damsa, I. (2011). Antifungal Capacity of Lactic Acid Bacteria Isolated From Salad Vegetables. Afr. J. Biomed. Res., 14, 137-141.

Akalin, A.S., Fenderya, S., \& Akbulut, N. (2004). Viability and Activity of Bifidobacteria in Yoghurt Containing Fructooligosaccharide During Refrigerated Storage. International Journal of Food Science and Technology, 39, 613-621.

Bamise, C.T \& Bamise, O.F. (2008). Quantifying The Acidic Content of Commercial Yoghurt Drinks in Nigeria. Int. J. Dent. Sci., 6 (1), 16.

Biyari, S \& Fozouni, L. (2018). The Inhibitory Effect of Probiotic Bacteria against Drug - Resistant Candida Species Isolated from the Oral Cavity of the Elderly. Shiraz E-Med J., 16 (6), 1-7.

Bulgasem, Y.B., Lani, M.Z., Hassan, Z., Yusofi, W.M.W., \& Fnaish, S.G. (2016). Antifungal Activity of Lactic Acid Bacteria Strains Isolated from Natural Honey against Pathogenic Candida spesies. Mycobiology, 44 (4), 302-309.

Bulgasem, B.Y., Hassan, Z., Huda-Faujan, N., Omar, R.H.A., Lani, M.N., \& Alshelmani, M.I. (2017). Effect of $\mathrm{pH}$, Heat Treatment and Enzymes on The Antifungal Activity of Lactic Acid Bacteria Against Candida Species. Malaysian Journal of Microbiology, 13 (3), 195-202.

Coman, M.M., Verdenelli, M.C., Cecchini, C., Silvi, S., Orpianesi, C., Boyko, N., \& Cresci, A. (2014). In Vitro Evaluation of Antimicrobial Activity of Lactobacillus rhamnosus IMC 501®, Lactobacillus paracasei IMC $502 \AA$ and SYNBIO ${ }^{\circledR}$. Journal of Applied Microbiology 117, 518527.

da Silva, D.C.G., Brugnera, D.F., \& de Abreu, L.R. (2013). Quantification of Lactic Acid Bacteria and Bifidobacteria in Goat Milk Based Yoghurts with Added Water-Soluble Soy Extract. Afr. J. Food Sci., 7, 10, 392-398.
Gravina, H.G., de Morán, E.G., Zambrano, O., Chourio, M.L., de Valero, S.R., Robertis, S., \& Mesa L. (2007). Oral Candidiasis in Children and Adolescents with Cancer. Identification of Candida spp.. Med Oral Patol Oral Cir Bucal., 12, E419-E423.

Guevarra, R.B., Virginia, L., \& Barraquio. (2015). Viable Counts of Lactic Acid Bacteria in Philippine Commercial Yoghurts. Int J Dairy Sci Process, 2, 5, 24-28.

Hakim, L \& Ramadhian, M.R. (2015). Kandidiasis Oral. Majority, 4 (8), 53-57.

Hartayanie, L., Lindayani., \& Murniati, M.P. (2015). Isolasi dan Identifikasi Bakteri Asam Laktat dari Asinan Rebung Bambu Betung yang Difermentasi pada Suhu $15^{\circ} \mathrm{C}$. Dalam: Kusumaningrum, H.P.,Lindyani, Nurjanah, S., Rukmi, MG.I., \& Gunawan, I. (eds). Prosiding Pertemuan Ilmiah Tahunan Perhimpunan Mikrobiologi Indonesia, 8-9 Oktober, Permi, Semarang, hlm. 216-223.

Hasrulliana, N,W., Suyoso, S., \& Rosita, C.S.P. (2010). Surabaya Manifestasi Klinis dan Identifikasi Spesies Penyebab Kandidiasis Oral pada Pasien HIV/ AIDS RSUD Dr.Soetomo Surabaya. Berkala Ilmu Kesehatan Kulit \& Kelamin, 22,1, 11-16.

Irianto, K. (2013). Mikrobiologi Medis. Alfabeta, Bandung. Hlm 363-364.

Khalil,Md.I\& Anwar, Md.N. (2016). Isolation, Identification and Characterization of Lactic Acid Bacteria from Milk and Yoghurts. RRJFPDT, 4, 3, 17-26.

Khikmah, N \& Sulistyani, N. (2017). Potensi Beberapa Susu Fermentasi Komersial Sebagai Antifungi Candida albicans. Biota, 2 (1), 14-20.

Lukisari, C., Setyaningtyas, D., \& Djamhari, M. (2010). Penatalaksanaan Kandidiasi Oral disebabkan Candida tropicalis pada Anak dengan Gangguan Sistemik. Dentofasial, 9 (2): 78-85.

Magnusson, J \& Schnurer, J. (2001). Lactobacillus coryniformis subsp. 
Khikmah et al.

coryniformis strain Si3 Produced a BroadSpectrum Proteinaceous Antifungal Compound. Appl. Environ. Microbiol., 67 (1), 1-5.

[NCCLS] National Committee for Clinical Laboratory Standard. (2002). Performance Standart for Antimicrobial Disc Susceptibility Testing. Twelfth International Supplement.

Parada, J.L., Caron, C.R., Medeiros, A.D.P. ,\& Soccol, C.R. (2007). Bacteriocins from Lactic Acid Bacteria: Purification, Properties and Use as Biopreservatives. Braz Arch Biol. Tech., 50, 521-524.

Pfaller, M.A \& Diekema, J.D. (2007). Epidemiology of Invasive Candidiasis: a Persistent Public Health Problem. Clinical Microbiology Reviews, 20 (1), 133-63.

Purwijantiningsih, E. (2011). Uji Antibakteri Yoghurt Sinbiotik Terhadap Beberapa Bakteri Patogen Enterik. Biota, 16 (2), 173-177.

Rahayu, E.S., Yogeswara, A., Mariyatun, Haryono, P., Utami, I.S., Utami, T., Nurfiani, S., \& Cahyanto, M.N. (2013). Bakteri Asam Laktat Indigenous Berpotensi Probiotik Dan Aplikasinya Untuk Produksi Susu Fermentasi. Dalam: Karmiadji, D.W., Gunadi, A.D., Soebagyo, H., \& Fazri, R. (eds). Prosiding Seminar Intensif Riset SINas, 7-8 November 2013, Kemristek, Jakarta, hlm. 149-159.

Rai, A.K., Bhaskar, N., Amani, P.M., Indriani, K., Suresh, P.V., \& Mahendrakar, N.S. (2009). Characterization and Aplication of Native Lactic Acid Bacterium Isolated From Tannery Fleshing for Fermentative Bioconversion of Tannery Fleshing. Application Microbiology Biotechnology, 83, 757-766.

Suskovic, J., Kos, B., Beganovic, J., Pavunc, A.L., Habjanic, K., \& Matosic, S. (2010). Antimicrobial Activity-The Most Important Property of Probiotic and
Sciscitatio, Vol. 1, No. 1, Januari 2020

Stater Lactic Acid Bacteria. Food Technol. Biotechnol., 48, 3, 296-307.

Shah, N.P. (2000). Probiotic Bacteria : Selective Enumeration and Survival in Dairy Food. Dairy Science J., 5: 515-521.

Urbiene, S \& Leskauskaite, D. (2006). Formation of Some Organic Acids During Fermentation of Milk. Pol. J. Food. Nutr. Sci., 15/16, 3, 277-281.

Walangare, T., Hidayat, T., \& Basuki, S. (2014). Profil Spesies Candida pada Pasien Kandidiasis Oral dengan Infeksi HIV \& AIDS. Berkala Ilmu Kesehatan Kulit \& Kelamin, 26, 1, 29-35.

Wibowo, W. (2002). Bioteknologi Fermentasi Susu. PusatPengembangan Bioteknologi. Universitas Muhammadiyah Malang. 